\title{
Top 100 articles on vitamin D: Bibliometric versus altmetric analysis
}

\author{
BEKTAN KANAT Bahar, YAVUZER Hakan \\ Division of Geriatric Medicine, Department of Internal Medicine, Cerrahpasa Medical Faculty, \\ Istanbul University-Cerrahpasa, Istanbul, Turkey. baharbektan@gmail.com
}

\begin{abstract}
OBJECTIVE: To analyse the main features of the top 100 (T100) most cited articles in academia and 100 most discussed articles on social media about vitamin D from 1975 to 2021 and compare bibliometric and altmetric analysis.

METHODS: 'Vitamin D' was searched from the Web of Science database and Altmetric.com website, and T100 citation and altmetric lists were created, respectively. Articles in both lists were analysed in terms of study type, topic, first author, publication year, citation number and altmetric attention score (AAS). Impact factor (IF) and quartile of journal, in which the articles were published was also examined.

RESULTS: The article "Vitamin D Deficiency" by Holick MF, published in the New England Journal of Medicine was the most cited article $(n=8492)$, original scientific paper was the most frequent study type in both lists. No correlation was found between AAS and citation number in both lists $(r=0.176, p=0.081$; $r=0.157, p=0.119$, respectively). The journals on the T100 citation list had a statistically significantly higher IF than the journals in the T100 altmetric list $(p<0.001)$.

CONCLUSION: Altmetric analysis of vitamin $D$ is currently insufficient to replace traditional bibliometric analysis but can provide valuable information about the society's interest. As social media gains more importance every day in our lives, high altmetric score could affect future interests and direct studies (Tab. 6, Fig. 3, Ref. 21). Text in PDF www.elis.sk

KEY WORDS: vitamin D, deficiency, fractures, COVID-19, bibliometric, altmetric.
\end{abstract}

\section{Introduction}

Vitamin D is a unique hormone that can be produced mostly in the skin by exposure to direct sunlight but also through dietary sources. Vitamin D receptors are present in most tissues and cells in the body (1). The relationship of vitamin $\mathrm{D}$ with many diseases has been investigated over the years. In addition to the risk of metabolic bone diseases, the risk of many common chronic diseases, including cancers, cardiovascular disease and autoimmune diseases may increase in the presence of vitamin D deficiency (2). Because of the popularity of vitamin D in many fields of health, including COVID-19, it is not surprising that there has been a significant number of studies about this topic over the past several decades.

Bibliometric and altmetric analyses provide important and different perspectives for research articles in both scientific world and community. The term "bibliometrics" was first used in 1969 and it was reported that bibliometric analysis could highly sensitively and

Division of Geriatric Medicine, Department of Internal Medicine, Cerrahpasa Medical Faculty, Istanbul University-Cerrahpasa, Istanbul, Turkey

Address for correspondence: Bahar BEKTAN KANAT, Division of Geriatric Medicine, Department of Internal Medicine, Cerrahpasa Medical Faculty, Istanbul University-Cerrahpasa, Cerrahpasa mahallesi Kocamustafapasa Caddesi No: 34/E Fatih, Istanbul, Turkey

Phone: +90.212 .4143000$ quantitatively measure scientific outputs based on geometrical and statistical methods (3). Today, bibliometric analysis is frequently used by academicians in different scientific disciplines including medicine to identify impactful papers in their fields $(4,5)$.

Altmetrics are non-traditional bibliometrics that was first proposed in year 2010 (6). As a result of the increase in the popularity of social media recently, researchers had the opportunity to present their academic studies to public more easily, so a concept called "altmetric analysis" was created. Altmetric attention score (AAS) obtained by altmetric analysis symbolizes the effect of articles on social media. Although it is a new analysis technique, there are many studies using this non-traditional method (7).

The number of citations is frequently used to determine the quality of articles. Similarly, the average number of citations of the publications in a journal is used to calculate the impact factor (IF) of a journal which is considered as an indicator of journal quality in academia (8). The term impact factor is generally used for journals, but can rarely be used for articles, too.

Although there are many studies about vitamin D, no prior studies to evaluate the relationship between traditional and nontraditional publication metrics in the field of vitamin D were conducted. In this study, we evaluated 100 most cited articles in academia and 100 most shared articles in social media about vitamin $\mathrm{D}$ and we aimed to analyse the relationship between bibliometrics and altmetrics on this topic. In addition, bibliometric mapping and 
Tab. 1. Top 100 Citation List.

\begin{tabular}{|c|c|c|c|c|c|}
\hline Rank and title & Year & First Author & $\begin{array}{l}\text { Times } \\
\text { Cited }\end{array}$ & $\begin{array}{l}\text { Average Citations } \\
\text { Per Year }\end{array}$ & $\begin{array}{l}\text { Altmetric } \\
\text { Score }\end{array}$ \\
\hline 1. Vitamin D Deficiency & 2007 & Holick MF & 8492 & 566,13 & 643 \\
\hline $\begin{array}{l}\text { 2. Evaluation, Treatment, and Prevention of Vitamin D Deficiency: an Endocrine } \\
\text { Society Clinical Practice Guideline }\end{array}$ & 2011 & Holick MF & 4746 & 431,45 & 1124 \\
\hline 3. Toll-like receptor triggering of a vitamin D-mediated human antimicrobial response & 2006 & Liu PT & 2406 & 150,38 & 59 \\
\hline $\begin{array}{l}\text { 4. The } 2011 \text { Report on Dietary Reference Intakes for Calcium and Vitamin D from } \\
\text { the Institute of Medicine: What Clinicians Need to Know }\end{array}$ & 2011 & Ross AC & 2263 & 205,73 & 172 \\
\hline 5. Vitamin-D(3) and calcium to prevent hip-fractures in elderly women & 1992 & Chapuy MC & 2167 & 72,23 & 95 \\
\hline 6. Decreased bioavailability of vitamin D in obesity & 2000 & Wortsman J & 1891 & 85,95 & 129 \\
\hline $\begin{array}{l}\text { 7. Estimation of optimal serum concentrations of } 25 \text {-hydroxyvitamin D for multiple } \\
\text { health outcomes }\end{array}$ & 2006 & Bischoff-Ferrari HA & 1626 & 101,63 & - \\
\hline 8. Prediction of bone-density from vitamin-D receptor alleles & 1994 & Morrison NA & 1609 & 57,46 & 12 \\
\hline 9. Vitamin D deficiency and risk of cardiovascular disease & 2008 & Wang TJ & 1593 & 113,79 & 141 \\
\hline $\begin{array}{l}\text { 10. Sunlight and vitamin } \mathrm{D} \text { for bone health and prevention of autoimmune diseases, } \\
\text { cancers, and cardiovascular disease }\end{array}$ & 2004 & Holick MF & 1559 & 86,61 & 168 \\
\hline $\begin{array}{l}\text { 11. Effect of calcium and vitamin D supplementation on bone density in men and } \\
\text { women } 65 \text { years of age or older }\end{array}$ & 1997 & DawsonHughes B & 1498 & 59,92 & - \\
\hline $\begin{array}{l}\text { 12. 1,25-Dihydroxyvitamin D-3 is a negative endocrine regulator of the renin- } \\
\text { angiotensin system }\end{array}$ & 2002 & $\mathrm{Li} \mathrm{YC}$ & 1417 & 70,85 & 11 \\
\hline 13. Vitamin D deficiency: a worldwide problem with health consequences & 2008 & Holick MF & 1376 & 98,29 & 245 \\
\hline $\begin{array}{l}\text { 14. Vitamin D deficiency and secondary hyperparathyroidism in the elderly: } \\
\text { Consequences for bone loss and fractures and therapeutic implications }\end{array}$ & 2001 & Lips $P$ & 1321 & 62,9 & 9 \\
\hline 15. Overview of general physiologic features and functions of vitamin D & 2004 & DeLuca HF & 1258 & 69,89 & 3 \\
\hline 16. Intake of vitamin $\mathrm{D}$ and risk of type 1 diabetes: a birth-cohort study & 2001 & Hypponen E & 1257 & 59,86 & 162 \\
\hline 17. Estimates of optimal vitamin D status & 2005 & Dawson-Hughes B & 1229 & 72,29 & 10 \\
\hline $\begin{array}{l}\text { 18. RXR-BETA - A Coregulator that enhances binding of retinoic acid, thyroid- } \\
\text { hormone, and vitamin-D receptors to their cognate response elements }\end{array}$ & 1991 & $\mathrm{Yu} \mathrm{VC}$ & 1228 & 39,61 & 12 \\
\hline $\begin{array}{l}\text { 19. The role of vitamin } \mathrm{D} \text { and calcium in type } 2 \text { diabetes. A systematic review and } \\
\text { meta-analysis }\end{array}$ & 2007 & Pittas AG & 1205 & 80,33 & 40 \\
\hline 20. Structure-function-relationships in the vitamin-D endocrine system & 1995 & Bouillon R & 1202 & 44,52 & - \\
\hline 21. Hypovitaminosis D is associated with insulin resistance and beta cell dysfunction & 2004 & Chiu KC & 1181 & 65,61 & - \\
\hline 22. Serum 25-hydroxyvitamin D levels and risk of multiple sclerosis & 2006 & Munger KL & 1159 & 72,44 & - \\
\hline 23. Calcium plus vitamin D supplementation and the risk of fractures & 2006 & Jackson RD & 1149 & 71,81 & 117 \\
\hline 24. High prevalence of vitamin D inadequacy and implications for health & 2006 & Holick MF & 1145 & 71,56 & 51 \\
\hline $\begin{array}{l}\text { 25. Vitamin D: importance in the prevention of cancers, type } 1 \text { diabetes, heart disease, } \\
\text { and osteoporosis }\end{array}$ & 2004 & Holick MF & 1077 & 59,83 & 195 \\
\hline 26. Hypovitaminosis D in medical inpatients & 1998 & Thomas MK & 1064 & 44,33 & - \\
\hline 27. Prevalence of vitamin D insufficiency in an adult normal population & 1997 & Chapuy MC & 1061 & 42,44 & 22 \\
\hline $\begin{array}{l}\text { 28. The nuclear vitamin D receptor: Biological and molecular regulatory properties } \\
\text { revealed }\end{array}$ & 1998 & Haussler MR & 1059 & 44,13 & 7 \\
\hline 29. FGF-23 is a potent regulator of vitamin D metabolism and phosphate homeostasis & 2004 & Shimada $\mathrm{T}$ & 1056 & 58,67 & 10 \\
\hline 30. Vitamin D and Human Health: Lessons from Vitamin D Receptor Null Mice & 2008 & Bouillon R & 1026 & 73,29 & 28 \\
\hline $\begin{array}{l}\text { 31. Common genetic determinants of vitamin D insufficiency: a genome-wide } \\
\text { association study }\end{array}$ & 2010 & Wang TJ & 1019 & 84,92 & 32 \\
\hline $\begin{array}{l}\text { 32. Targeted ablation of Fgf23 demonstrates an essential physiological role of FGF23 } \\
\text { in phosphate and vitamin D metabolism }\end{array}$ & 2004 & Shimada $\mathrm{T}$ & 999 & 55,5 & 17 \\
\hline $\begin{array}{l}\text { 33. Vitamin D and calcium supplementation reduces cancer risk: results of a } \\
\text { randomized trial }\end{array}$ & 2007 & Lappe Joan M & 992 & 66,13 & 464 \\
\hline 34. Vitamin D supplementation, 25-hydroxyvitamin D concentrations, and safety & 1999 & Vieth R & 986 & 42,87 & 81 \\
\hline $\begin{array}{l}\text { 35. Cutting edge: } 1,25 \text {-dihydroxyvitamin } \mathrm{D}-3 \text { is a direct inducer of antimicrobial } \\
\text { peptide gene expression }\end{array}$ & 2004 & Wang TT & 981 & 54,5 & - \\
\hline $\begin{array}{l}\text { 36. Fracture prevention with vitamin D supplementation - A meta-analysis of } \\
\text { randomized controlled trials }\end{array}$ & 2005 & Bischoff-Ferrari HA & 939 & 55,24 & 95 \\
\hline 37. The role of the vitamin-D endocrine system in health and disease & 1989 & Reichel H & 933 & 28,27 & 15 \\
\hline 38. Genetics and biology of vitamin D receptor polymorphisms & 2004 & Uitterlinden AG & 932 & 51,78 & 4 \\
\hline 39. Vitamin D signalling pathways in cancer: potential for anticancer therapeutics & 2007 & Deeb Kristin K & 928 & 61,87 & 43 \\
\hline $\begin{array}{l}\text { 40. Prevalence of abnormal serum vitamin D, PTH, calcium, and phosphorus in } \\
\text { patients with chronic kidney disease: Results of the study to evaluate early kidney } \\
\text { disease }\end{array}$ & 2007 & Levin A & 927 & 61,8 & 10 \\
\hline $\begin{array}{l}\text { 41. Human serum 25-hydroxycholecalciferol response to extended oral dosing with } \\
\text { cholecalciferol }\end{array}$ & 2003 & Heaney RP & 920 & 48,42 & - \\
\hline 42. Current understanding of the molecular actions of vitamin D & 1998 & Jones G & 920 & 38,33 & 13 \\
\hline
\end{tabular}




\begin{tabular}{|c|c|c|c|c|c|}
\hline Rank and title & Year & First Author & $\begin{array}{l}\text { Times } \\
\text { Cited }\end{array}$ & $\begin{array}{l}\text { Average Citations } \\
\text { Per Year }\end{array}$ & $\begin{array}{l}\text { Altmetric } \\
\text { Score }\end{array}$ \\
\hline $\begin{array}{l}\text { 43. } 1 \text { alpha,25-dihydroxyvitamin D-3 inhibits differentiation, maturation, activation, } \\
\text { and survival of dendritic cells leading to impaired alloreactive T cell activation }\end{array}$ & 2000 & Penna G & 919 & 41,77 & - \\
\hline 45. 25-hydroxyvitamin D levels and the risk of mortality in the general population & 2008 & Melamed Michal L & 907 & 64,79 & - \\
\hline 46. Global vitamin D status and determinants of hypovitaminosis D & 2009 & Mithal A & 898 & 69,08 & 48 \\
\hline 47. Effect of vitamin D on falls - A meta-analysis & 2004 & Bischoff-Ferrari HA & 883 & 49,06 & 35 \\
\hline $\begin{array}{l}\text { 49. Prevention of Rickets and Vitamin D Deficiency in Infants, Children, and } \\
\text { Adolescents }\end{array}$ & 2008 & Wagner CL & 870 & 62,14 & 84 \\
\hline $\begin{array}{l}\text { 50. Vitamin D supplementation and total mortality - A meta-analysis of randomized } \\
\text { controlled trials }\end{array}$ & 2007 & Autier P & 856 & 57,07 & 73 \\
\hline 51. Cloning and expression of full-length CDNA-encoding human vitamin-D receptor & 1988 & Baker AR & 844 & 24,82 & 9 \\
\hline $\begin{array}{l}\text { 52. 25-hydroxyvitamin D and risk of myocardial infarction in men - A prospective } \\
\text { study }\end{array}$ & 2008 & Giovannucci E & 833 & 59,5 & - \\
\hline 53. Vitamin effects on the immune system: vitamins A and D take centre stage & 2008 & Mora JR & 831 & 59,36 & 195 \\
\hline 54. Vitamin D: A millenium perspective & 2003 & Holick MF & 829 & 43,63 & 49 \\
\hline 55. Vitamin D Status: Measurement, Interpretation, and Clinical Application & 2009 & Holick MF & 826 & 63,54 & 25 \\
\hline $\begin{array}{l}\text { 56. Effect of four monthly oral vitamin D-3 (cholecalciferol) supplementation on } \\
\text { fractures and mortality in men and women living in the community: randomised } \\
\text { double blind controlled trial }\end{array}$ & 2003 & Trivedi DP & 826 & 43,47 & 49 \\
\hline 57. Distribution of the Vitamin D receptor and 1 alpha-hydroxylase in human brain & 2005 & Eyles DW & 816 & 48 & 88 \\
\hline 58. Resurrection of vitamin D deficiency and rickets & 2006 & Holick MF & 807 & 50,44 & 372 \\
\hline $\begin{array}{l}\text { 59. Mice lacking the vitamin D receptor exhibit impaired bone formation, uterine } \\
\text { hypoplasia and growth retardation after weaning }\end{array}$ & 1997 & Yoshizawa T & 806 & 32,24 & 8 \\
\hline $\begin{array}{l}\text { 60. Circulating } 25 \text {-hydroxyvitamin D levels indicative of vitamin D sufficiency: } \\
\text { Implications for establishing a new effective dietary intake recommendation for } \\
\text { vitamin D }\end{array}$ & 2005 & Hollis BW & 791 & 46,53 & - \\
\hline $\begin{array}{l}\text { 61. Annual High-Dose Oral Vitamin D and Falls and Fractures in Older Women A } \\
\text { Randomized Controlled Trial }\end{array}$ & 2010 & Sanders KM & 789 & 65,75 & 271 \\
\hline $\begin{array}{l}\text { 63. Transcriptional activation of the Cdk inhibitor p } 21 \text { by vitamin D-3 leads to the } \\
\text { induced differentiation of the myelomonocytic cell line U937 }\end{array}$ & 1996 & Liu M & 786 & 30,23 & - \\
\hline 64. Redefining vitamin D insufficiency & 1998 & Malabanan A & 780 & 32,5 & 19 \\
\hline 65. Vitamin D receptor as an intestinal bile acid sensor & 2002 & Makishima M & 760 & 38 & - \\
\hline $\begin{array}{l}\text { 66. Prospective study of predictors of vitamin D status and cancer incidence and } \\
\text { mortality in men }\end{array}$ & 2006 & Giovannucci E & 752 & 47 & - \\
\hline $\begin{array}{l}\text { 67. Demographic Differences and Trends of Vitamin D Insufficiency in the US } \\
\text { Population, 1988-2004 }\end{array}$ & 2009 & Ginde AA. & 739 & 56,85 & 228 \\
\hline $\begin{array}{l}\text { 68. Vitamin D deficiency in children and its management: Review of current } \\
\text { knowledge and recommendations }\end{array}$ & 2008 & Misra M & 727 & 51,93 & - \\
\hline 69. Vitamin D-2 is much less effective than vitamin D-3 in humans & 2004 & Armas LAG & 723 & 40,17 & 108 \\
\hline $\begin{array}{l}\text { 70. } 1 \text { alpha,25-dihydroxyvitamin D3 has a direct effect on naive CD4(+) T cells to } \\
\text { enhance the development of Th2 cells }\end{array}$ & 2001 & Boonstra A & 721 & 34,33 & - \\
\hline $\begin{array}{l}\text { 71. An endocytic pathway essential for renal uptake and activation of the steroid 25- } \\
(\mathrm{OH}) \text { vitamin D-3 }\end{array}$ & 1999 & Nykjaer A & 702 & 30,52 & - \\
\hline $\begin{array}{l}\text { 72. Hypovitaminosis D prevalence and determinants among African American } \\
\text { and white women of reproductive age: third National Health and Nutrition } \\
\text { Examination Survey, 1988-1994 }\end{array}$ & 2002 & Nesby-O`DS & 696 & 34,8 & - \\
\hline 73. Extrarenal expression of 25-hydroxyvitamin D-3-1 alpha-hydroxylase & 2001 & Zehnder D & 696 & 33,14 & - \\
\hline 74. Vitamin D physiology & 2006 & Lips P & 692 & 43,25 & 40 \\
\hline 75. Calcium plus vitamin D supplementation and the risk of colorectal cancer & 2006 & Wactawski-Wende J & 691 & 43,19 & 50 \\
\hline 76. Vitamin D intake and incidence of multiple sclerosis & 2004 & Munger KL & 688 & 38,22 & 53 \\
\hline $\begin{array}{l}\text { 77. Low vitamin D and high parathyroid hormone levels as determinants of loss of } \\
\text { muscle strength and muscle mass (Sarcopenia): The Longitudinal Aging Study } \\
\text { Amsterdam }\end{array}$ & 2003 & Visser M & 688 & 36,21 & 83 \\
\hline $\begin{array}{l}\text { 78. Human cathelicidin antimicrobial peptide (CAMP) gene is a direct target } \\
\text { of the vitamin D receptor and is strongly up-regulated in myeloid cells by } \\
1,25 \text {-dihydroxyvitamin D-3 }\end{array}$ & 2005 & Gombart AF & 680 & 40 & 1 \\
\hline $\begin{array}{l}\text { 79. The vitamin-D endocrine system - Steroid metabolism, hormone receptors, and } \\
\text { biological response (calcium-binding proteins) }\end{array}$ & 1982 & Norman AW & 675 & 16,88 & 3 \\
\hline $\begin{array}{l}\text { 80. Vitamin D supplementation improves cytokine profiles in patients with congestive } \\
\text { heart failure: a double-blind, randomized, placebo-controlled trial }\end{array}$ & 2006 & Schleithoff SS & 671 & 41,94 & 25 \\
\hline
\end{tabular}




\begin{tabular}{|c|c|c|c|c|c|}
\hline Rank and title & Year & First Author & $\begin{array}{l}\text { Times } \\
\text { Cited }\end{array}$ & $\begin{array}{l}\text { Average Citations } \\
\text { Per Year }\end{array}$ & $\begin{array}{l}\text { Altmetric } \\
\text { Score }\end{array}$ \\
\hline 81. The role of vitamin $\mathrm{D}$ in cancer prevention & 2006 & Garland CF & 668 & 41,75 & 141 \\
\hline $\begin{array}{l}\text { 82. Targeted ablation of the vitamin D receptor: An animal model of vitamin } \\
\text { D-dependent rickets type II with alopecia }\end{array}$ & 1997 & $\mathrm{Li} \mathrm{YC}$ & 667 & 26,68 & 6 \\
\hline $\begin{array}{l}\text { 83. Serum 25-hydroxyvitamin D, diabetes, and ethnicity in the Third National Health } \\
\text { and Nutrition Examination Survey }\end{array}$ & 2004 & Scragg $\mathrm{R}$ & 662 & 36,78 & - \\
\hline $\begin{array}{l}\text { 84. Activated injectable vitamin D and hemodialysis survival: A historical cohort } \\
\text { study }\end{array}$ & 2005 & Teng $\mathrm{M}$ & 653 & 38,41 & - \\
\hline $\begin{array}{l}\text { 85. The crystal structure of the nuclear receptor for vitamin D bound to its natural } \\
\text { ligand }\end{array}$ & 2000 & Rochel N & 653 & 29,68 & 12 \\
\hline $\begin{array}{l}\text { 86. Fall prevention with supplemental and active forms of vitamin D: a meta-analysis } \\
\text { of randomised controlled trials }\end{array}$ & 2009 & Bischoff-Ferrari HA & 647 & 49,77 & 35 \\
\hline $\begin{array}{l}\text { 87. Vitamin D-Binding Protein and Vitamin D Status of Black Americans and White } \\
\text { Americans }\end{array}$ & 2013 & Powe CE & 645 & 71,67 & 297 \\
\hline 88. Vitamin D: modulator of the immune system & 2010 & Baeke F & 645 & 53,75 & 25 \\
\hline $\begin{array}{l}\text { 89. Higher 25-hydroxyvitamin D concentrations are associated with better lower- } \\
\text { extremity function in both active and inactive persons aged }>=60 \mathrm{y}\end{array}$ & 2004 & Bischoff-Ferrari HA & 644 & 35,78 & - \\
\hline 90. Modulatory effects of 1,25-dihydroxyvitamin D-3 on human B cell differentiation & 2007 & Chen S & 640 & 42,67 & - \\
\hline 91. Noncalcemic actions of vitamin D receptor ligands & 2005 & Nagpal S & 637 & 37,47 & 19 \\
\hline 92. Do sunlight and vitamin-D reduce the likelihood of colon cancer? & 1980 & Garland CF & 636 & 15,14 & 50 \\
\hline 93. Plasma 25-hydroxyvitamin D levels and risk of incident hypertension & 2007 & FormanJP & 634 & 42,27 & - \\
\hline 94. The role of vitamin $\mathrm{D}$ in reducing cancer risk and progression & 2014 & Feldman D & 632 & 79 & 227 \\
\hline $\begin{array}{l}\text { 95. Oral vitamin D3 and calcium for secondary prevention of low-trauma fractures in } \\
\text { elderly people (Randomised Evaluation of Calcium Or vitamin D, RECORD): a } \\
\text { randomised placebo-controlled trial }\end{array}$ & 2005 & Grant AM & 629 & 37 & 15 \\
\hline $\begin{array}{l}\text { 96. Effects of vitamin D and calcium supplementation on falls: A randomized } \\
\text { controlled trial }\end{array}$ & 2003 & Bischoff-Ferrari HA & 628 & 33,05 & 12 \\
\hline $\begin{array}{l}\text { 97. Dietary vitamin-D and calcium and risk of colorectal cancer-A } 19 \text { year } \\
\text { prospective study in men }\end{array}$ & 1985 & Garland C & 627 & 16,95 & 18 \\
\hline $\begin{array}{l}\text { 98. Calcium absorption varies within the reference range for serum } \\
25 \text {-hydroxyvitamin D }\end{array}$ & 2003 & Heaney RP & 625 & 32,89 & - \\
\hline 99. Vitamin D status and ill health: a systematic review & 2014 & Autier P & 620 & 77,5 & 371 \\
\hline $\begin{array}{l}\text { 100. Prevalence of cardiovascular risk factors and the serum levels of } \\
\text { 25-hydroxyvitamin D in the United States - Data from the Third National Health } \\
\text { and Nutrition Examination Survey }\end{array}$ & 2007 & Martins D & 614 & 40,93 & - \\
\hline
\end{tabular}

text mining were performed to determine and display the keywords of the articles in T100 citation list, words in the abstract and the authors' countries.

\section{Methods}

\section{Data collection and inclusion criteria}

Citation information for vitamin D was obtained from Thomson Reuters Web of Science (WoS) database. All of the articles, published between the years 1975-2021, related to the keyword "vitamin D" were searched in English on March 4, 2021 and 104.796 articles were obtained. Since WoS database lists all the articles containing vitamin D in any of the title, abstract, keywords, keywords plus; the articles not primarily related to vitamin D were excluded to create the T100 citation list with the consensus of the authors. PubMed was also utilized to find data about the articles. All the top 100 citation and altmetric articles were analysed and information on topic of the articles, types of research methods, journal of publication, first author, year of publication, citation counts and also average number of citations per year was extracted. IF and Quartile (Q) rankings of the journals in which the articles were published, for the year 2019 were used. IF is calculated by dividing the current year citation score to the total number of articles published in that journal during the previous two years and is calculated yearly for journals listed in the Journal Citation Reports (8). Q index describes the rank of a journal in a specific field and scores of the same journal may vary according to the scientific categories. Each subject category of journals is divided into four quartiles and Q1 indicates the top $25 \%$ journals in the same field. The ranking of the journals that had 2 or more articles in the T100 lists were given in detail with IF values and Q categories.

Similarly, the keyword "vitamin D" was searched on the Altmetric.com website on March 4, 2021 and the T100 altmetric list was created by excluding unrelated articles (9). The Altmetric Attention Score (AAS) is a weighted count of the online attention received by a scholarly article. Online attention comes from non-traditional sources, including mainstream media, social media (Facebook, Twitter, LinkedIn, Google+, Sin Weibo and Pinterest), public policy documents, post-publication peer-review platforms, Open Syllabus Project, blogs, citations, research highlights, multimedia and other online platforms (YouTube, Reddit, Q\&A), patents, online reference managers and Wikipedia (10). AAS is derived from three main factors including volume, sources and 
Tab. 2. Top 100 Altmetric List.

\begin{tabular}{|c|c|c|c|c|}
\hline Rank and title & Year & First Author & $\begin{array}{l}\text { Altmetric } \\
\text { Score }\end{array}$ & $\begin{array}{l}\text { Times } \\
\text { Cited }\end{array}$ \\
\hline $\begin{array}{l}\text { 1. Vitamin D supplementation to prevent acute respiratory tract infections: systematic review and } \\
\text { meta-analysis of individual participant data }\end{array}$ & 2017 & Martineau AR & 6444 & 492 \\
\hline $\begin{array}{l}\text { 2. Effects of vitamin D supplementation on musculoskeletal health: a systematic review, meta- } \\
\text { analysis, and trial sequential analysis }\end{array}$ & 2018 & Bolland MJ & 2973 & 141 \\
\hline $\begin{array}{l}\text { 3. Association Between Calcium or Vitamin D Supplementation and Fracture Incidence in } \\
\text { Community-Dwelling Older Adults: A Systematic Review and Meta-analysis }\end{array}$ & 2017 & Zhao JG & 2812 & 197 \\
\hline $\begin{array}{l}\text { 5. Evidence that Vitamin D Supplementation Could Reduce Risk of Influenza and COVID-19 } \\
\text { Infections and Deaths }\end{array}$ & 2020 & Grant WB & 2601 & 416 \\
\hline 6. Vitamin D Supplements and Prevention of Cancer and Cardiovascular Disease & 2019 & Manson JE & 2292 & 411 \\
\hline $\begin{array}{l}\text { 7. Analysis of vitamin D level among asymptomatic and critically ill COVID-19 patients and its } \\
\text { correlation with inflammatory markers }\end{array}$ & 2020 & Jain A & 2164 & 16 \\
\hline 8. The role of Vitamin D in the prevention of Coronavirus Disease 2019 infection and mortality & 2020 & Ilie PC & 1819 & 159 \\
\hline $\begin{array}{l}\text { 9. Autumn COVID-19 surge dates in Europe correlated to latitudes, not to temperature-humidity, } \\
\text { pointing to vitamin D as contributing factor }\end{array}$ & 2021 & Walrand S & 1719 & 0 \\
\hline 10. Vitamin D Deficiency Is There Really a Pandemic? & 2016 & Manson JE & 1602 & 133 \\
\hline $\begin{array}{l}\text { 11. Vitamin D Insufficiency May Account for Almost Nine of Ten COVID-19 Deaths: Time to Act. } \\
\text { Comment on: Vitamin D Deficiency and Outcome of COVID-19 Patient. Nutrients 2020, } 12,25\end{array}$ & 2020 & Brenner H & 1551 & 2 \\
\hline $\begin{array}{l}\text { 12. Vitamin D sufficiency, a serum } 25 \text {-hydroxyvitamin D at least } 30 \mathrm{ng} / \mathrm{mL} \text { reduced risk for adverse } \\
\text { clinical outcomes in patients with COVID-19 infection }\end{array}$ & 2020 & Maghbooli Z & 1456 & 28 \\
\hline $\begin{array}{l}\text { 13. Vitamin D Deficiency, Its Role in Health and Disease, and Current Supplementation } \\
\text { Recommendations }\end{array}$ & 2017 & Pfotenhauer KM & 1422 & 18 \\
\hline 14. Vitamin D and COVID-19: evidence and recommendations for supplementation & 2020 & Griffin $\mathrm{G}$ & 1360 & 0 \\
\hline 15. Vitamin D and the Immune System & 2015 & Aranow C & 1322 & 350 \\
\hline $\begin{array}{l}\text { 16. Effect of Monthly High-Dose Vitamin D Supplementation on Cardiovascular Disease in the } \\
\text { Vitamin D Assessment Study }\end{array}$ & 2017 & Scragg R & 1170 & 159 \\
\hline $\begin{array}{l}\text { 17. Evaluation, Treatment, and Prevention of Vitamin D Deficiency: an Endocrine Society Clinical } \\
\text { Practice Guideline }\end{array}$ & 2011 & Holick MF & 1124 & 4746 \\
\hline 18. Impact of Serum 25(OH) Vitamin D Level on Mortality in Patients with COVID-19 in Turkey & 2020 & Karahan S & 1117 & 0 \\
\hline $\begin{array}{l}\text { 19. Vitamin D deficiency as a predictor of poor prognosis in patients with acute respiratory failure } \\
\text { due to COVID-19 }\end{array}$ & 2020 & Carpagnano GE & 1024 & 28 \\
\hline $\begin{array}{l}\text { 21. Effect of High-Dose Vitamin D Supplementation on Volumetric Bone Density and Bone } \\
\text { Strength }\end{array}$ & 2019 & Burt LA & 1015 & 71 \\
\hline 22. Vitamin D and the risk of dementia and Alzheimer disease & 2014 & Littlejohns TJ & 1005 & 232 \\
\hline 23. Epidemic influenza and vitamin D & 2007 & Aloia JF & 983 & 180 \\
\hline 24. Prevalence and correlates of vitamin D deficiency in US adults & 2011 & Forrest KY & 977 & 481 \\
\hline $\begin{array}{l}\text { 25. Randomized trial of vitamin D supplementation to prevent seasonal influenza A in } \\
\text { schoolchildren }\end{array}$ & 2010 & Urashima M & 943 & 509 \\
\hline 26. Vitamin D for COVID-19: a case to answer? & 2020 & Martineau AR & 915 & 30 \\
\hline $\begin{array}{l}\text { 27. Maternal gestational vitamin D supplementation and offspring bone health (MAVIDOS): a } \\
\text { multicentre, double-blind, randomised placebo-controlled trial }\end{array}$ & 2016 & Cooper C & 887 & 103 \\
\hline $\begin{array}{l}\text { 28. Circulating Vitamin D and Colorectal Cancer Risk: An International Pooling Project of } 17 \\
\text { Cohorts }\end{array}$ & 2018 & McCullough ML & 832 & 75 \\
\hline $\begin{array}{l}\text { 29. The economic case for prevention of population vitamin D deficiency: a modelling study using } \\
\text { data from England and Wales }\end{array}$ & 2019 & Aguiar M & 825 & 7 \\
\hline $\begin{array}{l}\text { 30. Determinants of the Maternal 25-Hydroxyvitamin D Response to Vitamin D Supplementation } \\
\text { During Pregnancy }\end{array}$ & 2016 & Moon RJ & 794 & 19 \\
\hline 31. Vitamin D for the management of asthma & 2016 & Martineau AR & 791 & 106 \\
\hline 32. Vitamin D and survival in COVID-19 patients: A quasi-experimental study & 2020 & Annweile C & 787 & 16 \\
\hline 33. Relation between milk-fat percentage, vitamin D, and BMI z score in early childhood & 2016 & Vanderhout SM & 770 & 20 \\
\hline 34. Role of Magnesium in Vitamin D Activation and Function & 2018 & Uwitonze AM & 750 & 70 \\
\hline $\begin{array}{l}\text { 35. Vitamin D Supplementation and Cardiovascular Disease Risks in More Than } 83000 \text { Individuals } \\
\text { in } 21 \text { Randomized Clinical Trials }\end{array}$ & 2019 & Barbarawi M & 745 & 54 \\
\hline $\begin{array}{l}\text { 36. Dose responses of vitamin D3 supplementation on arterial stiffness in overweight African } \\
\text { Americans with vitamin D deficiency: A placebo controlled randomized trial }\end{array}$ & 2017 & Raed A & 743 & 25 \\
\hline $\begin{array}{l}\text { 37. Relationships between hyperinsulinaemia, magnesium, vitamin } \mathrm{D} \text {, thrombosis and COVID-19: } \\
\text { rationale for clinical management }\end{array}$ & 2020 & Cooper ID & 742 & 3 \\
\hline 38. Gestational vitamin D deficiency and autism-related traits: the Generation R Study & 2016 & Vinkhuyzen AAE & 737 & 54 \\
\hline 39. Vitamin D concentrations and COVID-19 infection in UK Biobank & 2020 & Hastie CE & 735 & 8 \\
\hline 40. Vitamin D Supplementation and Prevention of Type 2 Diabetes & 2019 & Pittas AG & 733 & 137 \\
\hline
\end{tabular}




\begin{tabular}{|c|c|c|c|c|}
\hline Rank and title & Year & First Author & $\begin{array}{l}\text { Altmetric } \\
\text { Score }\end{array}$ & $\begin{array}{l}\text { Times } \\
\text { Cited }\end{array}$ \\
\hline 41. Effect of Vitamin D3 Supplements on Development of Advanced Cancer & 2020 & Chandler PD & 732 & 0 \\
\hline $\begin{array}{l}\text { 42. Vitamin D, Calcium, or Combined Supplementation for the Primary Prevention of Fractures in } \\
\text { Community-Dwelling Adults }\end{array}$ & 2018 & Kahwati LC & 706 & 64 \\
\hline $\begin{array}{l}\text { 43. Low plasma } 25(\mathrm{OH}) \text { vitamin } \mathrm{D} \text { level is associated with increased risk of COVID-19 infection: } \\
\text { an Israeli population-based study }\end{array}$ & 2020 & Merzon E & 702 & 41 \\
\hline $\begin{array}{l}\text { 44. Cohort study to evaluate the effect of combination vitamin D, magnesium and vitamin B-12 } \\
\text { (DMB) on progression to severe outcome in older patients with coronavirus (COVID-19) }\end{array}$ & 2020 & Tan CW & 666 & 10 \\
\hline 45. Association of Serum Level of Vitamin D at Diagnosis With Breast Cancer Survival & 2017 & Yao S & 662 & 57 \\
\hline 46. Sunlight and Vitamin D: Necessary for Public Health & 2015 & Baggerly CA & 659 & 57 \\
\hline 47. Monthly High-Dose Vitamin D Treatment for the Prevention of Functional Decline & 2016 & Bischoff-F & 657 & 251 \\
\hline 48. A Statistical Error in the Estimation of the Recommended Dietary Allowance for Vitamin D & 2014 & Veugelers PJ & 655 & 36 \\
\hline $\begin{array}{l}\text { 49. Effects of vitamin D supplements on bone mineral density: a systematic review and meta- } \\
\text { analysis }\end{array}$ & 2014 & Reid IR & 647 & 295 \\
\hline 50. Vitamin D Deficiency & 2007 & Holick MF & 643 & 8492 \\
\hline 51. Vitamin D deficiency contributes directly to the acute respiratory distress syndrome (ARDS) & 2015 & Dancer RCA & 641 & 94 \\
\hline 52. Vitamin D and Health Outcomes: Then Came the Randomized Clinical Trials & 2019 & Lucas A & 592 & 5 \\
\hline 53. Use of vitamin D drops leading to kidney failure in a 54-year-old man & 2019 & Auguste BL & 590 & 4 \\
\hline $\begin{array}{l}\text { 54. Vitamin D associates with improved quality of life in participants with irritable bowel } \\
\text { syndrome: outcomes from a pilot trial }\end{array}$ & 2015 & Tazzyman S & 581 & 17 \\
\hline 55. Effect of Vitamin D and Calcium Supplementation on Cancer Incidence in Older Women & 2017 & Lappe J & 577 & 119 \\
\hline 56. Vitamin D Status and Rates of Cognitive Decline in a Multiethnic Cohort of Older Adults & 2015 & Miller JW & 577 & 97 \\
\hline $\begin{array}{l}\text { 57. New Approach to Develop Optimized Sunscreens that Enable Cutaneous Vitamin D Formation } \\
\text { with Minimal Erythema Risk }\end{array}$ & 2016 & Kockott D & 573 & 9 \\
\hline $\begin{array}{l}\text { 58. Latitude, urbanization, age, and sex as risk factors for vitamin D deficiency disease in the } \\
\text { Roman Empire }\end{array}$ & 2018 & Mays S & 573 & 8 \\
\hline $\begin{array}{l}\text { 59. Vitamin D supplementation to the older adult population in Germany has the cost-saving } \\
\text { potential of preventing almost } 30000 \text { cancer deaths per year }\end{array}$ & 2021 & Niedermaier T & 558 & 0 \\
\hline $\begin{array}{l}\text { 60. Vitamin D and multiple health outcomes: umbrella review of systematic reviews and meta- } \\
\text { analyses of observational studies and randomised trials }\end{array}$ & 2014 & Theodoratou E & 557 & 497 \\
\hline $\begin{array}{l}\text { 61. Vitamin D Supplementation Improves Cognitive Function Through Reducing Oxidative Stress } \\
\text { Regulated by Telomere Length in Older Adults with Mild Cognitive Impairment: A 12-Month } \\
\text { Randomized Controlled Trial }\end{array}$ & 2020 & Yang T & 540 & 0 \\
\hline $\begin{array}{l}\text { 62. Effect of Vitamin D Supplementation, Omega-3 Fatty Acid Supplementation, or a Strength- } \\
\text { Training Exercise Program on Clinical Outcomes in Older Adults } \\
\end{array}$ & 2020 & Bischoff-F & 537 & 9 \\
\hline 63. A Trial of Calcium and Vitamin D for the Prevention of Colorectal Adenomas & 2015 & Baron JA & 535 & 160 \\
\hline $\begin{array}{l}\text { 64. Trends in Use of High-Dose Vitamin D Supplements Exceeding } 1000 \text { or } 4000 \text { International } \\
\text { Units Daily, 1999-2014 }\end{array}$ & 2017 & Rooney MR & 528 & 53 \\
\hline $\begin{array}{l}\text { 65. Vitamin D and Calcium Supplementation to Prevent Fractures in Adults: U.S. Preventive } \\
\text { Services Task Force Recommendation Statement }\end{array}$ & 2013 & Moyer VA & 527 & 155 \\
\hline 66. Vitamin D deficiency aggravates COVID-19: systematic review and meta-analysis & 2020 & Pereira M & 525 & 15 \\
\hline 67. Vitamin D metabolites and the gut microbiome in older men & 2020 & Thomas RL & 516 & 1 \\
\hline 68. Vitamin D and risk of pregnancy related hypertensive disorders: mendelian randomisation study & 2018 & Magnus MC & 512 & 10 \\
\hline $\begin{array}{l}\text { 69. Editorial: low population mortality from COVID-19 in countries south of latitude } 35 \text { degrees } \\
\text { North supports vitamin D as a factor determining severity }\end{array}$ & 2020 & Rhodes JM & 499 & 69 \\
\hline $\begin{array}{l}\text { 70. Relationship Between Neonatal Vitamin D at Birth and Risk of Autism Spectrum Disorders: the } \\
\text { NBSIB Study }\end{array}$ & 2017 & Wu DM & 499 & 28 \\
\hline 71. Vitamin D for Health: A Global Perspective & 2013 & Hossein-nezhad A & 491 & 558 \\
\hline 72. Vitamin D and African Americans & 2006 & Harris SS & 476 & 210 \\
\hline 73. Vitamin D deficiency and depression in adults: systematic review and meta-analysis & 2018 & Anglin RES & 475 & 347 \\
\hline $\begin{array}{l}\text { 74. Assessment of vitamin D concentration in non-supplemented professional athletes and healthy } \\
\text { adults during the winter months in the UK: implications for skeletal muscle function }\end{array}$ & 2013 & Close GL & 466 & 130 \\
\hline 75. Exercise and Vitamin D in Fall Prevention Among Older Women & 2015 & Uusi-Rasi K & 464 & \\
\hline $\begin{array}{l}\text { 76. High-Dose Monthly Vitamin D for Prevention of Acute Respiratory Infection in Older Long- } \\
\text { Term Care Residents: A Randomized Clinical Trial }\end{array}$ & 2016 & Ginde AA & 464 & 45 \\
\hline 77. Vitamin D and calcium supplementation reduces cancer risk: results of a randomized trial & 2007 & Lappe JM. & 464 & 992 \\
\hline $\begin{array}{l}\text { 78. Vitamin D is Not Associated With Severity in NAFLD: Results of a Paired Clinical and Gene } \\
\text { Expression Profile Analysis }\end{array}$ & 2016 & Patel YA & 455 & 25 \\
\hline 79. Should adults take vitamin D supplements to prevent disease? & 2016 & Bolland MJ & 451 & 11 \\
\hline 80. Athletic Performance and Vitamin D & 2009 & Cannell JJ & 446 & 153 \\
\hline 81. Prevention of benign paroxysmal positional vertigo with vitamin D supplementation & 2020 & Jeong SH & 444 & 3 \\
\hline 82. Effect of Vitamin D Supplementation on Testosterone Levels in Men & 2011 & Pilz S & 440 & 132 \\
\hline $\begin{array}{l}\text { 83. Vitamin D and the omega-3 fatty acids control serotonin synthesis and action, part 2: relevance } \\
\text { for ADHD, bipolar disorder, schizophrenia, and impulsive behavior }\end{array}$ & 2015 & Patrick RP & 438 & 163 \\
\hline
\end{tabular}




\begin{tabular}{|c|c|c|c|c|}
\hline Rank and title & Year & First Author & $\begin{array}{l}\text { Altmetric } \\
\text { Score }\end{array}$ & $\begin{array}{l}\text { Times } \\
\text { Cited }\end{array}$ \\
\hline $\begin{array}{l}\text { 84. Predisposing role of vitamin D receptor (VDR) polymorphisms in the development of multiple } \\
\text { sclerosis: A case-control study }\end{array}$ & 2016 & Abdollahzadeh R & 436 & 18 \\
\hline 85. Should healthy people take a vitamin D supplement in winter months? & 2016 & Spector TD & 432 & 4 \\
\hline 86. Sorting Out Whether Vitamin D Deficiency Raises COVID-19 Risk & 2021 & Rubin R & 430 & 1 \\
\hline $\begin{array}{l}\text { 87. Vitamin D supplementation to prevent asthma exacerbations: a systematic review and meta- } \\
\text { analysis of individual participant data }\end{array}$ & 2017 & Jolliffe DA & 427 & 117 \\
\hline $\begin{array}{l}\text { 88. Folate and vitamin B12 concentrations are associated with plasma DHA and EPA fatty acids in } \\
\text { European adolescents: the Healthy Lifestyle in Europe by Nutrition in Adolescence (HELENA) } \\
\text { study }\end{array}$ & 2017 & Iglesia I & 427 & 9 \\
\hline 89. Estimation of Total Usual Calcium and Vitamin D Intakes in the United States & 2010 & Bailey RL & 424 & 354 \\
\hline 90. Treatment of Vitamin D Insufficiency in Postmenopausal Women: A Randomized Clinical Trial & 2015 & Hansen KE & 417 & 84 \\
\hline 91. Vitamin D status in pediatric irritable bowel syndrome & 2017 & Nwosu BU & 416 & 11 \\
\hline $\begin{array}{l}\text { 92. The Relationship between } 25(\mathrm{OH}) \text { D Levels (Vitamin D) and Bone Mineral Density (BMD) in } \\
\text { a Saudi Population in a Community-Based Setting }\end{array}$ & 2017 & Alkhenizan A & 415 & 11 \\
\hline $\begin{array}{l}\text { 93. Association between vitamin D supplementation and mortality: systematic review and meta- } \\
\text { analysis }\end{array}$ & 2019 & Zhang Y & 409 & 49 \\
\hline 94. Vitamin D and Calcium for the Prevention of Fracture & 2019 & Yao P & 406 & 32 \\
\hline $\begin{array}{l}\text { 95. Association Between Myopia, Ultraviolet B Radiation Exposure, Serum Vitamin D } \\
\text { Concentrations, and Genetic Polymorphisms in Vitamin D Metabolic Pathways in a } \\
\text { Multicountry European Study }\end{array}$ & 2017 & Williams KM & 402 & 29 \\
\hline $\begin{array}{l}\text { 96. Vitamin D Insufficiency and Deficiency and Mortality from Respiratory Diseases in a Cohort } \\
\text { of Older Adults: Potential for Limiting the Death Toll during and beyond the COVID-19 } \\
\text { Pandemic? }\end{array}$ & 2020 & Brenner H & 402 & 7 \\
\hline 97. Understanding vitamin D deficiency & 2014 & Sahota $\mathrm{O}$ & 401 & 25 \\
\hline 98. The association between neonatal vitamin D status and risk of schizophrenia & 2018 & Eyles DW & 400 & 21 \\
\hline 99. Serum 25 -hydroxyvitamin $\mathrm{D}$, vitamin $\mathrm{D}$ binding protein, and prostate cancer risk in black men & 2017 & Layne TM & 395 & 12 \\
\hline $\begin{array}{l}\text { 100. Effects of Vitamin D on Cardiac Function in Patients With Chronic HF: The VINDICATE } \\
\text { Study }\end{array}$ & 2016 & Witte KK & 393 & 96 \\
\hline
\end{tabular}

\section{Tab. 3. Journals in the top 100 Citation List.}

\begin{tabular}{lccc}
\hline Rank and Journal & $\begin{array}{c}\text { The Number } \\
\text { of Articles }\end{array}$ & $\begin{array}{c}\text { Impact } \\
\text { Factor* }\end{array}$ & $\begin{array}{c}\text { Quartile in } \\
\text { Category** }\end{array}$ \\
\hline 1. American Journal of Clinical Nutrition & 13 & 6,77 & $\mathrm{Q} 1$ \\
\hline 2. New England Journal of Medicine & 8 & 74,70 & $\mathrm{Q} 1$ \\
\hline 3. Lancet & 6 & 60,39 & $\mathrm{Q} 1$ \\
\hline 4. Archives of Internal Medicine & 6 & 17,33 & $\mathrm{Q} 1$ \\
\hline 5. Journal of Clinical Endocrinology \& Metabolism & 6 & 5,40 & $\mathrm{Q} 1$ \\
\hline 6. Endocrine Reviews & 5 & 14,66 & $\mathrm{Q} 1$ \\
\hline 7. Journal of the American Medical Association & 4 & 45,54 & $\mathrm{Q} 1$ \\
\hline 8. Journal of Immunology & 4 & 4,89 & $\mathrm{Q} 2$ \\
\hline 9. Journal of Clinical Investigation & 3 & 11,86 & $\mathrm{Q} 1$ \\
\hline 10. Journal of Bone and Mineral Research & 3 & 5,95 & $\mathrm{Q} 1$ \\
\hline 11. Osteoporosis International & 3 & 3,86 & $\mathrm{Q} 2$ \\
\hline 12. Nature Reviews Cancer & 2 & 53,03 & $\mathrm{Q} 1$ \\
\hline 13. Cell & 2 & 38,64 & $\mathrm{Q} 1$ \\
\hline 14. British Medical Journal & 2 & 30,31 & $\mathrm{Q} 1$ \\
\hline 15. Proceedings of the National Academy of Sciences \\
of the United States of America & 2 & 9,41 & $\mathrm{Q} 1$
\end{tabular}

* 2019 Journal Citation Reports (Clarivate Analytics), **2019 Scimago Journal and Country Rank, ***Journals with 2 or more articles in the top 100 citation list is given.

authors and represented in the donut-shaped graphic. AAS appears in the middle of altmetric donut and colours of the donut represent different sources of attention. Area occupied by the source in donut indicates the source's contribution to AAS. Mendeley readers and Citeulike bookmarks do not contribute to the donut or score (11). In addition, the AAS of the top 100 cited articles was obtained from the Altmetric.com website, and the citation counts of the top
100 altmetric articles were obtained from the WoS website on the same date.

Countries of the authors were recorded. Among the authors of the article, those of the same geographic origin were registered only once. VOSviewer was used to visualize the keywords of the articles in the T100 citation list, countries of the authors, and words in the abstract section and also to display bibliometric maps.

\section{Statistical analysis}

Categorical variables were defined as the median (minimum - maximum). Since the data was not normally distributed, Mann -Whitney U test was used to compare the differences between the 2 groups; and Kruskal-Wallis test was used to compare 3 or more groups. Spearman correlation analysis was performed to evaluate the correlation between citation count and AAS in both lists. We performed statistical analyses using IBM SPSS-20 (Statistical Package for Social Sciences, Chicago, Illinois, USA).

\section{Results}

Top cited 100 articles about vitamin D are given in the Table 1 ; with the number of citations, AAS, altmetric score donut, ave- 
Tab. 4. Journals in the top 100 Altmetric List.

\begin{tabular}{lccc}
\hline Rank and Journal & $\begin{array}{c}\text { The Number } \\
\text { of Articles }\end{array}$ & $\begin{array}{c}\text { Impact } \\
\text { Factor* }\end{array}$ & $\begin{array}{c}\text { Quartile in } \\
\text { Category** }\end{array}$ \\
\hline 1. Journal of the American Medical Association & 8 & 45,54 & Q1 \\
\hline 2. British Medical Journal & 7 & 30,31 & Q1 \\
\hline 3. New England Journal of Medicine & 5 & 74,70 & Q1 \\
\hline 4. PLoS ONE & 5 & 2,74 & Q2 \\
\hline 5. Nutrients & 4 & 4,55 & Q1 \\
\hline 6. Lancet Diabetes \& Endocrinology & 3 & 25,34 & Q1 \\
\hline 7. JAMA Internal Medicine & 3 & 18,65 & Q1 \\
\hline 8. American Journal of Clinical Nutrition & 3 & 6,77 & Q1 \\
\hline 9. JAMA Network Open & 3 & 5,03 & Q1 \\
\hline 10. Scientific Reports & 3 & 4,00 & Q1 \\
\hline 11. JAMA Cardiology & 2 & 12,79 & Q1 \\
\hline 12. Neurology & 2 & 8,77 & Q1 \\
\hline 13. Journal of Clinical Endocrinology \& Metabolism & 2 & 5,40 & Q1 \\
\hline 14. Journal of Nutrition & 2 & 4,28 & Q1 \\
\hline * 2019 Journal Citation Reports (Clarivate Analytics), ** 2019 Scimago Journal and Country Rank, ***Journals \\
with 2 or more articles in the top 100 altmetric list is given \\
\end{tabular}

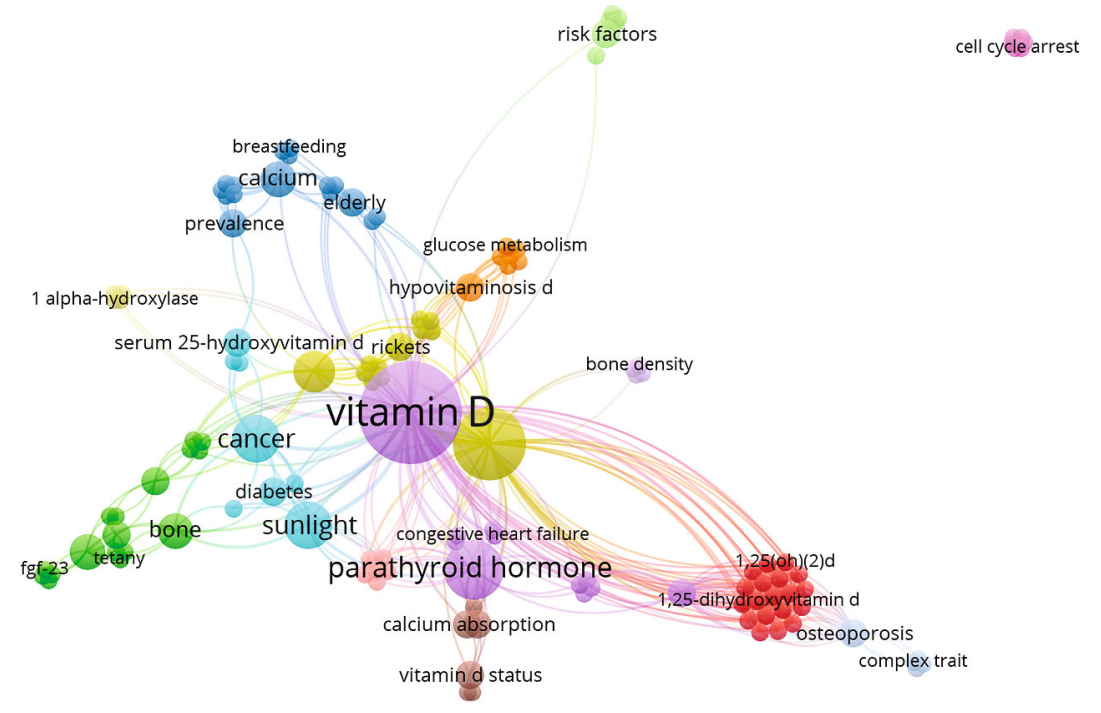

monocytes

Fig. 1. The most common keywords in the T100 citation list.

rage citations per year, first author and year of publication. The median of the citation count of the top 100 cited articles was 850 (IQR, 614-8,492), while the median for AAS was 17,5 (IQR, 0-1124). The article entitled "Vitamin D Deficiency" by Holick MF published in the New England Journal of Medicine in 2007 was the most cited article on both lists $(\mathrm{n}=8492)($ rank 1 in table 1$)$ (1). The highest altmetric score $(\mathrm{n}=1124)$ in the T100 citation list belonged to the second most cited article $(n=4746)$ entitled "Evaluation, Treatment, and Prevention of Vitamin D Deficiency: an Endocrine Society Clinical Practice Guideline" again by Holick MF et al, published in the Journal of Clinical Endocrinology \& Metabolism in 2011 (rank 2 in table 1) (12). Time period since publication median was 16 years (range: 7-31). The Spearman correlation analysis was used to define the correlation between the citation number and AAS of the T100 citation articles, but no statistically significant correlation was found between the citation number and AAS $(\mathrm{r}=0.176 ; \mathrm{p}=0.081)$.

Table 2 (T100 altmetric list) includes 100 articles about vitamin D with the highest AAS, as well as the number of citations, altmetric score donut, first author and year of publication of the articles. The median AAS of the top 100 altmetric articles was 642 (IQR, 393-6444) and the citation number median for the same list was 46 (IQR, 0-8492). The article entitled "Vitamin D supplementation to prevent acute respiratory tract infections: systematic review and meta-analysis of individual participant data" written by Martineau AR et al. and published in the British Medical Journal in 2017, had the highest altmetric score ( $n=$ 6444 ) in the top 100 altmetric list while the citation count of the article was 492 (rank 1 in table 2) (13). Time period since publication median was 4 years (range: $0-15$ ). There was no correlation between the citation number and AAS of the T100 altmetric articles according to Spearman correlation analysis $(r=0.157 ; p=0.119)$.

There were only three common articles in both lists (rank 1, rank 2 and rank 33 in table 1). One of the common articles was "Vitamin D and calcium supplementation reduces cancer risk: results of a randomized trial" by Lappe JM published in the American Journal of Clinical Nutrition in 2007 (rank 33 in table 1) (14). The other common articles were the first two articles in T100 citation list, as mentioned before (rank 1 and rank 2 in table 1).

Journals with the most published articles in the T100 citation list was the American Journal of Clinical Nutrition $(\mathrm{n}=13)$, New England Journal of Medicine $(n=8)$ and Archives of Internal Medicine $(n=6)$ respectively, while the most frequently encountered journal in the T100 altmetric list was the Journal of the American Medical Association $(n=8)$. The median IF of the journals in T100 citation list was 9.46 (IQR, 2.18-74.69) and for the T100 altmetric list it was 6.76 (IQR, 1.21-74.69). In our study, $79.5 \%(n=35)$ of the journals in the T100 citation list and $45.9 \%(n=39)$ of the journals in the T100 altmetric list were Q1 according to the Scimago Journal and Country Rank category. IF values of the journals, in which the articles in both lists were published, were summed up for each list and divided by the number of articles. While the 


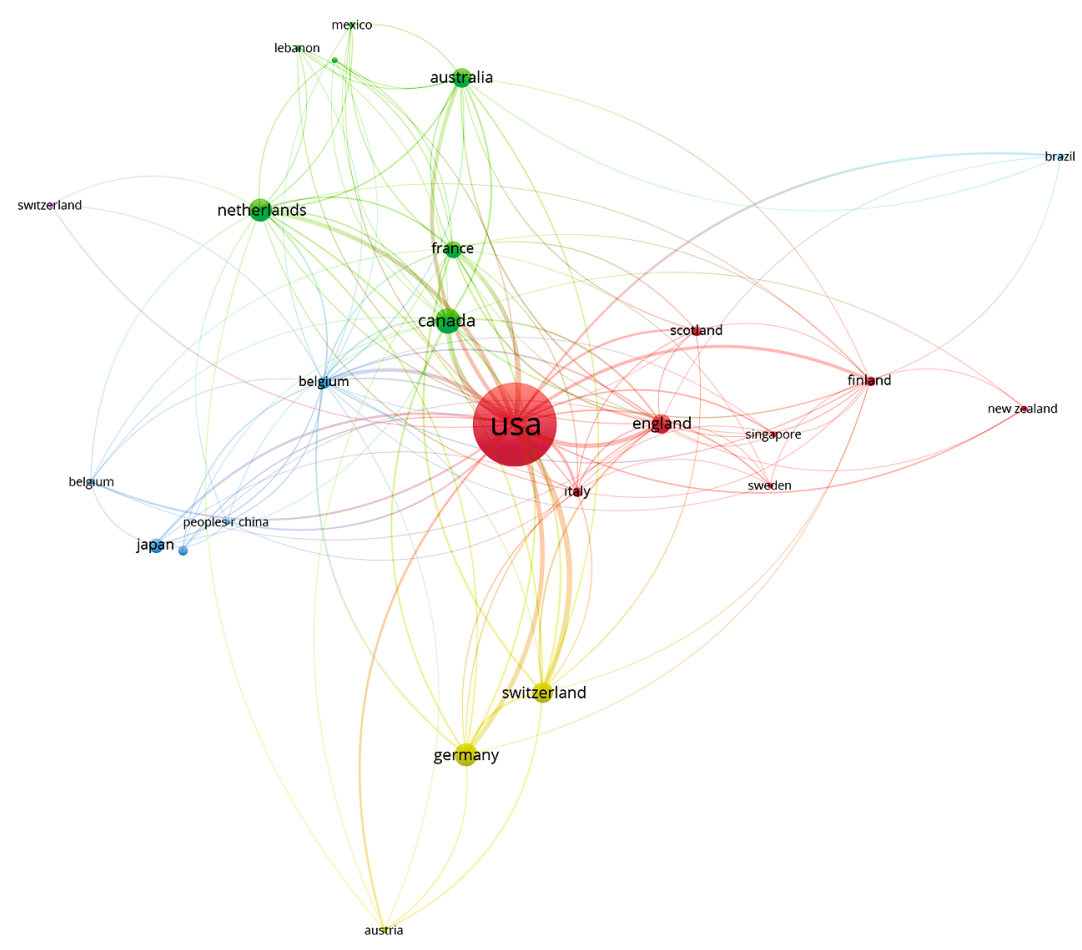

Fig. 2. Countries of the authors and network of countries.

journals of the articles on the T100 citation list had a statistically significantly higher IF value than the journals in the T100 altmetric list $(\mathrm{p}<0.001)$, there was no statistically significant difference between $\mathrm{Q}$ categories in both lists $(\mathrm{p}=0.058)$. The publication language was English for all articles. Journals with two or more articles in both lists, published article counts of the journals, IF values and Q categories are given in Tables 3 and 4, respectively.
The most common keywords in the T100 citation list were vitamin D, 25-hydroxyvitamin $\mathrm{D}$, parathyroid hormone and sunlight as shown in Figure 1 with the link strength relationship in a network visualization cluster map. USA had the distinction of being the country of most of the authors that had articles in T100 citation list. Countries of the authors and network of countries are given in Figure 2. Figure 3 shows the words exceeding 5 or more times in the abstract sections of the articles with connections. The most prominent word in the red coloured cluster, one of the 3 clusters, was vitamin D receptor. In the green coloured cluster d level; and in the blue cluster fracture and trial was foremost and had the most link strength.

Study types were categorized into the 3 groups as original scientific paper, review, and others. Original scientific paper was the most frequent study type followed by review in both lists. According to article types; while there was no difference between altmetric scores in the T100 altmetric list $(p=0.492)$, there was a significant difference between the number of citations $(p=0.028)$. On the other hand, while there was no significant difference between the number of citations according to article types in the T100 citation list $(p=0.158)$, there was a statistically significant difference between the altmetric scores $(p=0.001)$. Study types of the two lists and statistical analysis according to study types are given in Table 5 . Top 100 cited articles were divided into 4 groups as pathophysio-

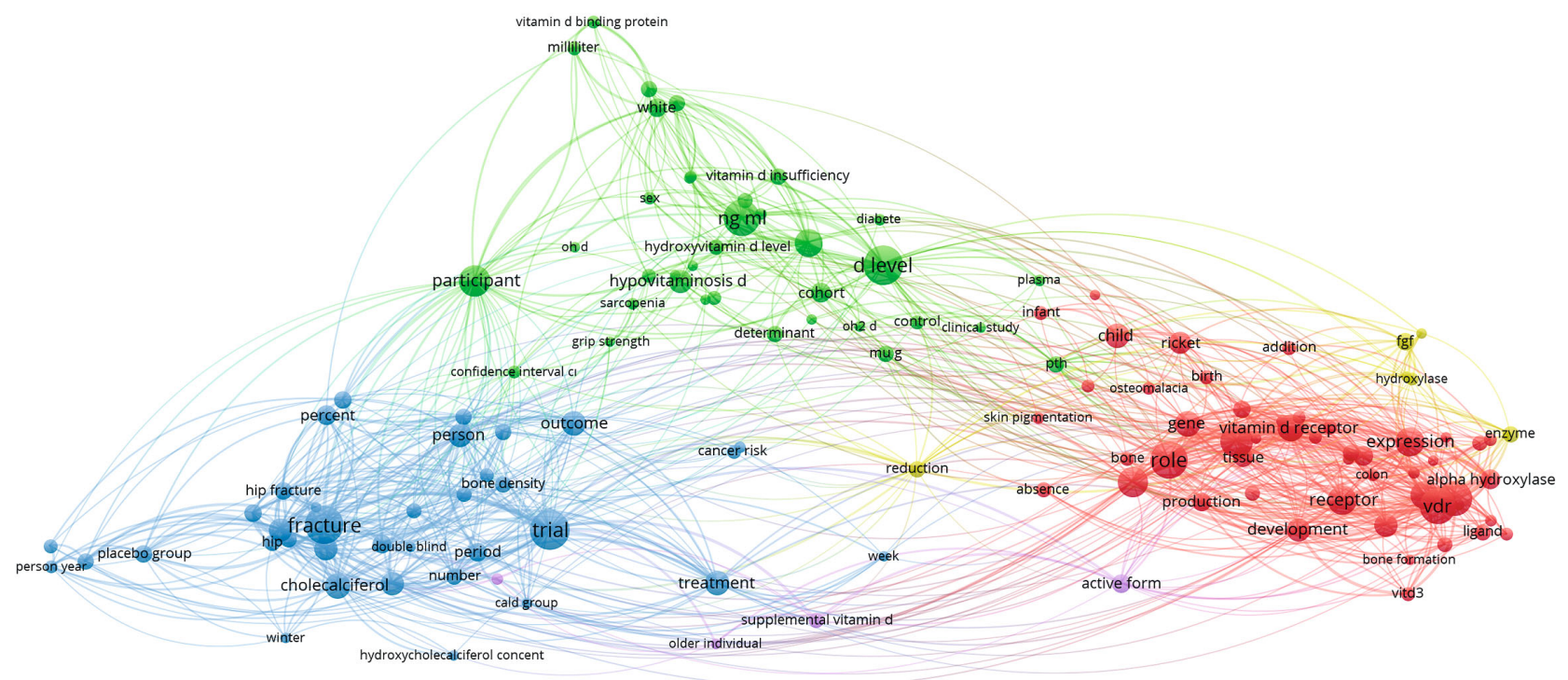

Fig. 3. Correlation and clusters of words exceeding 5 or more times in the abstract sections of the most cited 100 articles. 
logy, aetiology-risk factors, prevention and others in terms of topic. In the T100 citation list, most publications were on pathophysio$\log y(n=33)$ while there were only a few articles $(n=4)$ on this topic in the altmetric list. The number of articles on aetiology and risk factors was similar between the two lists $(n=24, n=25$, respectively). In the T100 citation list, according to the article topics; there was no difference between the groups in terms of the citation counts $(p=0.857)$, but there was a statistically significant difference in AAS $(p=0.019)$. When the articles in the T100 altmetric list were evaluated according to topics, no statistically significant difference was found in terms of both AAS and citation count ( $p$ $=0.475, \mathrm{p}=0.135$, respectively). Table 6 shows the topics of articles in both lists and statistical analysis according to the topics.

Evaluating the first authors of the top 100 cited articles, the leading first authors were Holick MF with 9 articles and Bischoff-
Ferrari HA with 6 articles. Holick MF has also the distinction of being the author of the first two top cited articles on the list (Tab. 1). The years, in which most of the top 100 cited articles were published, were 2004 with 13 articles and for the top 100 altmetric articles it was 2020 with 23 articles, 18 of which was about COVID-19 (Tabs 1 and 2).

\section{Discussion}

There are many studies about Vitamin D in literature, but only a few bibliometric or altmetric studies were performed. As far as we know, our study is the first comparative study of bibliometric and altmetric analyses of the top 100 most cited articles in academia and top 100 most discussed articles on social media on the topic vitamin D. In 2019, Caballero-Villarraso J et al wrote a

Tab. 5. Study types of the articles in top 100 Altmetric and Citation List.

\begin{tabular}{|c|c|c|c|c|c|}
\hline Study Type & Number of articles & $\begin{array}{c}\text { Citations, } \\
\text { median } \\
\text { (minimum-maximum) }\end{array}$ & $\mathrm{p}$ & $\begin{array}{c}\text { AAS, } \\
\text { median } \\
\text { (minimum-maximum) }\end{array}$ & $\mathrm{p}$ \\
\hline Top 100 citation list & 100 & $850(614-8492)$ & & $17(0-1124)$ & \\
\hline Original scientific paper & 57 & $806(614-2167)$ & \multirow{5}{*}{0.158} & $10(0-464)$ & \multirow{5}{*}{0.001} \\
\hline Review & 34 & $924(632-8492)$ & & $45(0-643)$ & \\
\hline Others & 9 & & & & \\
\hline Systematic reviews and meta-analyses & 7 & \multirow{2}{*}{$856(620-4746)$} & & \multirow{2}{*}{$73(0-1124)$} & \\
\hline Guidelines and advisory documents & 2 & & & & \\
\hline Top 100 altmetric list & 100 & $46(0-8492)$ & & $642(393-6444)$ & \\
\hline Original scientific paper & 57 & $28(0-992)$ & \multirow{7}{*}{0.028} & $581(393-2716)$ & \multirow{7}{*}{0.492} \\
\hline Review & 31 & $53(0-8492)$ & & $659(401-2601)$ & \\
\hline Others & 12 & \multirow{5}{*}{$148(15-4746)$} & & \multirow{5}{*}{$587(406-6444)$} & \\
\hline Systematic reviews and meta-analyses & 6 & & & & \\
\hline Editorial & 3 & & & & \\
\hline Guidelines and advisory documents & 2 & & & & \\
\hline Case report & 1 & & & & \\
\hline
\end{tabular}

Tab. 6. Topics of the articles in top 100 Citation and Altmetric List.

\begin{tabular}{|c|c|c|c|c|c|}
\hline Topic & Number of articles & $\begin{array}{c}\text { Citations, } \\
\text { median } \\
\text { (minimum-maximum) }\end{array}$ & $\mathrm{p}$ & $\begin{array}{c}\text { AAS, } \\
\text { median } \\
\text { (minimum-maximum) }\end{array}$ & $\mathrm{p}$ \\
\hline Top 100 citation list & 100 & $850(614-8492)$ & & $17(0-1124)$ & \\
\hline Pathophysiology & 33 & $844(637-2406)$ & \multirow{7}{*}{0.857} & $8(0-195)$ & \multirow{7}{*}{0.019} \\
\hline Etiology and risk factors & 24 & $844(620-1891)$ & & $30(0-464)$ & \\
\hline Prevention & 11 & $870(629-2167)$ & & $81(0-141)$ & \\
\hline Others & 32 & & & & \\
\hline Combination & 23 & & & & \\
\hline Epidemiology, Policy & 6 & $863(614-8492)$ & & $45(0-1124)$ & \\
\hline Treatment & 3 & & & & \\
\hline Top 100 altmetric list & 100 & $46(0-8492)$ & & $642(393-6444)$ & \\
\hline Etiology and risk factors & 25 & $28(0-350)$ & \multirow{7}{*}{0.135} & $577(395-1551)$ & \multirow{7}{*}{0.475} \\
\hline Prevention & 23 & $119(0-992)$ & & $706(406-6444)$ & \\
\hline Treatment & 15 & $30(5-509)$ & & $666(417-943)$ & \\
\hline Others & 37 & & & & \\
\hline Combination & 32 & & & & \\
\hline Pathophysiology & 4 & $25(0-8492)$ & & $573(393-2716)$ & \\
\hline Epidemiology, Policy & 1 & & & & \\
\hline
\end{tabular}

AAS - Altmetric Attention Score 
systematic review that evaluates the effects of vitamin D on neurodegeneration using bibliometric analysis and drew attention to the growing evolution of research about vitamin D over the last decade (15). Brüggmann et al presented an analysis of the global research productivity on vitamin D and emphasized that highincome countries such as the USA has written most of the highimpact articles and led numerous collaborations (16). Similarly, in our study, the country with the highest number of articles in the T100 citation list was the USA.

The fact that there are 31 articles with more than 1000 citations in the T100 citation list and 68 articles with an altmetric score over 500 in the T100 altmetric list shows that both the academic community and social media are closely interested in this topic. We found no correlation between citation count and AAS in both T100 citation and T100 altmetric list. Contrary to our study, Huang $\mathrm{W}$ et al found a significant positive correlation between citation count and AAS in their studies (17).

In the T100 citation list "Vitamin D deficiency" by Holick MF published in New England Journal Of Medicine in 2007 was the most cited article with 8492 citation (1). It was one of the common articles in both T100 citation and altmetric lists and had 643 AAS. The article was a review about the role of vitamin D in health and makes recommendations for the prevention and treatment of vitamin D deficiency. The second most cited article "Evaluation, Treatment, and Prevention of Vitamin D Deficiency: an Endocrine Society Clinical Practice Guideline" by (again) Holick MF et al, published in Journal Of Clinical Endocrinology \& Metabolism in 2011, was a comprehensive guide for vitamin D deficiency and cited 4746 times (10). The article took place in both of the T100 lists and was very popular with 1124 AAS on social media as well. The third most cited article, with 2406 citation score, “Toll-like receptor triggering of a vitamin D-mediated human antimicrobial response" written by Liu PT et al. and published in Science in 2006 was a genome study, in which the link between Toll-like receptors and vitamin D-mediated innate immunity was found (18).

When we examined the top 3 articles of the T100 altmetric list, we come across vitamin D supplementation. In the T100 altmetric list "Vitamin D supplementation to prevent acute respiratory infections: systematic review and meta-analysis of individual participant data", by Martineau AR published in the British Medical Journal in 2017, had the highest AAS with 6444 (13). 25 eligible randomised controlled studies were evaluated in the article and vitamin D supplementation was found to be safe and protective against acute respiratory tract infections. The reason for having such high AAS may be the COVID-19 pandemic that has affected the whole world since December 2019 and the significant attention of social media users to COVID-19. "Effects of vitamin D supplementation on musculoskeletal health: a systematic review, meta-analysis, and trial sequential analysis" by Bolland MJ et al, published in the Lancet Diabetes \& Endocrinology in 2018, had the second highest AAS with 2973 (19). 81 randomised controlled trials, reporting fracture, falls or bone mineral density were identified, and it was concluded that vitamin D supplementation did not prevent fractures or falls, nor had clinically meaningful effects on bone mineral density. The article with the third highest AAS ( $n=$
2812) was "Association Between Calcium or Vitamin D Supplementation and Fracture Incidence in Community-Dwelling Older Adults : A Systematic Review and Meta-analysis" written by Zhao JG et al. and published in the Journal of the American Medical Association in 2017 (20). Randomized clinical trials comparing calcium, vitamin D, or combined calcium and vitamin D supplements with a placebo or no treatment for fracture incidence in community-dwelling adults older than 50 years was selected and as the result the use of supplements was not found to be associated with a lower risk of fractures, thus the routine use of the supplements in this population were not supported.

When we evaluated the topics of articles in both lists, we found differences. The number of articles on pathophysiology was higher in the T100 citation list $(\mathrm{n}=33)$ than the T100 altmetric list $(n=4)$. This result shows the curiosity of the academic community to pathophysiology, a specific subject, unlike the general public. Interest in vitamin $\mathrm{D}$, vitamin D deficiency and vitamin D-related diseases grows more and more every year both in the scientific world and social media. Confirming this, in our study, the topic with the highest number of articles in the altmetric list and the second highest number of articles in the citation list was aetiology and risk factors ( $n=25, n=24$, respectively). In a quantitative and co-word analysis, which aims to predict the future research topic trend by evaluating 4625 articles on vitamin D in 2019 , the epidemiological study of vitamin D deficiency and vitamin D-related diseases are found to be popular research topics similar to ours (21).

The number of articles about COVID-19 in the T100 altmetric list was 20 while no article on this topic was found in T100 citation list. Although it has not been long since the emergence of the COVID-19 pandemic, the fact that there are so many articles on this subject in the altmetric list shows how important social media is in our lives. Vitamin D, an inexpensive, easily available and wellknown vitamin, has become a hope for people in the prevention and treatment of COVID-19, about which there are still unknown.

The most frequently determined journal, in which the articles on the T100 citation list were published was the American Journal of Clinical Nutrition $(n=13)$ with a 74.69 IF value, while the most frequently encountered journal in the T100 altmetric list was the Journal of the American Medical Association $(n=8)$ with a 45.54 IF. IF of the journals of the articles on the T100 citation list was statistically significantly higher than the journals in the altmetric list $(\mathrm{p}<0.001)$. This can be attributed to the fact that citation count and AAS are different parameters and do not correlate with each other.

Our study has limitations. One of the limitations is the evaluation of the number of citations over the total number of citations; cited article analysis or self-citation analysis was not performed. The other limitation is that citation counts of the articles in both of the lists were obtained from the WoS database and articles not found in the database were not included in the lists.

Vitamin D is a hot topic in both academia and social media. Altmetric analysis of vitamin D is currently insufficient to replace traditional bibliometric analysis, but it can provide valuable information about the society's interest in this issue. As social me- 
dia gains more importance every day in our lives, high altmetric score could affect future interests and direct studies. As well as the number of citations, increasing the altmetric score, which shows the public awareness of the articles is an issue that should be considered important by academicians.

\section{References}

1. Holick MF. Vitamin D deficiency. N Engl J Med 2007; 357 (3): 266-281. DOI: 10.1056/NEJMra070553.

2. Holick MF, Chen TC. Vitamin D deficiency: a worldwide problem with health consequences. Am J Clin Nutr 2008; 87 (4): 1080S-1086S. DOI: $10.1093 / \mathrm{ajcn} / 87.4 .1080 \mathrm{~S}$.

3. Pritchard A. Statistical Bibliography or Bibliometrics. J Doc 1969; 25 (4): 348-349. (Dalpé R. Bibliometric analysis of biotechnology. Scientometrics 2002; 55: 189-213.)

4. Devos P, Menard J. Bibliometric analysis of research relating to hypertension reported over the period 1997-2016. J Hypertens 2019; 37 (11): 2116-2122. DOI: 10.1097/HJH.0000000000002143.

5. Brandt JS, Hadaya O, Schuster M, Rosen T, Sauer MV, Ananth CV. A Bibliometric Analysis of Top-Cited Journal Articles in Obstetrics and Gynecology. JAMA Netw Open 2019; 2 (12): e1918007. DOI: 10.1001/ jamanetworkopen.2019.18007.

6. Priem J, Taraborelli D, Groth P, Neylon C. "Altmetrics: A manifesto (v 1.01)". Altmetrics September 28, 2011.

7. Suzan V, Unal D. Comparison of attention for malnutrition research on social media versus academia: Altmetric score analysis. Nutrition 2020; 82: 111060. DOI: 10.1016/j.nut.2020.111060.

8. Garfield E. Citation indexes for science. A new dimension in documentation through association of ideas 1955. Int J Epidemiol 2006; 35 (5): 1123-1128. DOI: 10.1093/ije/dyl189.

9. https: //www.altmetric.com/explorer. Accessed: 4 March 2021.

10. https: //www.altmetric.com/about-our-data/our-sources/. Accessed: 4 March 2021.

11. https: //www.altmetric.com/about-our-data/the-donut-and-score/. Accessed: 4 March 2021.

12. Holick MF, Binkley NC, Bischoff-Ferrari HA, Gordon CM, Hanley DA, Heaney RP, Murad MH, Weaver CM; Endocrine Society. Evaluation, treatment, and prevention of vitamin D deficiency: an Endocrine Society clinical practice guideline. J Clin Endocrinol Metab 2011; 96 (7): 1911-1930. DOI: 10.1210/jc.2011-0385.
13. Martineau AR, Jolliffe DA, Greenberg L, Aloia JF, Bergman P, Dubnov-Raz G, Esposito S, Ganmaa D, Ginde AA, Goodall EC, Grant CC, Janssens W, Jensen ME, Kerley CP, Laaksi I, Manaseki-Holland S, Mauger D, Murdoch DR, Neale R, Rees JR, Simpson S, Stelmach I, Trilok Kumar G, Urashima M, Camargo CA, Griffiths CJ, Hooper RL. Vitamin D supplementation to prevent acute respiratory infections: individual participant data meta-analysis. Health Technol Assess 2019; 23 (2): 1-44. DOI: 10.3310/hta23020.

14. Lappe JM, Travers-Gustafson D, Davies KM, Recker RR, Heaney RP. Vitamin D and calcium supplementation reduces cancer risk: results of a randomized trial. Am J Clin Nutr 2007; 85 (6): 1586-1591. DOI: 10.1093/ajcn/85.6.1586.

15. Caballero-Villarraso J, Jiménez-Jiménez MJ, Escribano BM, Agüera E, Santamaría A, Túnez I. Implications of Vitamin D in Multiple Sclerosis and Other Neurodegenerative Processes: Bibliometric Analysis and Systematic Review. CNS Neurol Disord Drug Targets 2019; 18 (6): 478-490. DOI: 10.2174/1871527318666190703102330.

16. Brüggmann D, Alafi A, Jaque J, Klingelhöfer D, Bendels MH, Ohlendorf D, Quarcoo D, Louwen F, Ingles SA, Wanke EM, Groneberg DA. World-wide research architecture of vitamin D research: densityequalizing mapping studies and socio-economic analysis. Nutr J 2018; 17 (1): 3. DOI: 10.1186/s12937-018-0313-6.

17. Huang W, Wang P, Wu Q. A correlation comparison between Altmetric Attention Scores and citations for six PLOS journals. PLoS One 2018; 13 (4): e0194962. DOI: 10.1371/journal.pone.0194962.

18. Liu PT, Stenger S, Li H, Wenzel L, Tan BH, Krutzik SR, Ochoa MT, Schauber J, Wu K, Meinken C, Kamen DL, Wagner M, Bals R, Steinmeyer A, Zügel U, Gallo RL, Eisenberg D, Hewison M, Hollis BW, Adams JS, Bloom BR, Modlin RL. Toll-like receptor triggering of a vitamin D-mediated human antimicrobial response. Science 2006; 311 (5768): 1770-1773. DOI: 10.1126/science.1123933.

19. Bolland MJ, Grey A, Avenell A. Effects of vitamin D supplementation on musculoskeletal health: a systematic review, meta-analysis, and trial sequential analysis. Lancet Diabetes Endocrinol 2018; 6 (11): 847-858. DOI: 10.1016/S2213-8587 (18)30265-1.

20. Zhao JG, Zeng XT, Wang J, Liu L. Association Between Calcium or Vitamin D Supplementation and Fracture Incidence in CommunityDwelling Older Adults: A Systematic Review and Meta-analysis. JAMA 2017; 318 (24): 2466-2482. DOI: 10.1001/jama.2017.19344.

21. Yang A, Lv Q, Chen F, Wang D, Liu Y, Shi W. Identification of Recent Trends in Research on Vitamin D: A Quantitative and Co-Word Analysis. Med Sci Monit 2019; 25: 643-655. DOI: 10.12659/MSM.913026.

Received September 23, 2021. Accepted November 23, 2021. 